201.

\title{
高速 S EによるT2強調撮像法の検討
}

Study of Fast Spin-Echo Sequences

聖マリアン十䀢科大学東横病院放射線部

○五十嵐隆幸 米田充 佐藤卓夫 井村摩喜男 水谷和正 小泉美都枝 川添修身 (R. Igarasi) (H. Yoneda) (T. Satou) (H. Inura) (K. Mizutani)(M. Koizumi)(0. Kawazoe) 東芝那須工場MR技術部 山口弘次郎 高井博司 五老健应

$$
\text { (K. Yanaguti) (H. Takai) (T. Gorou) }
$$

[目的］現在，高速撮影法の開発がさかんであるが，撮像時間の 短緥だけでなく臨休的に有効な画質であるかがもうひとつの課題 である。今回, マルチエコー法を用いた高速 $\mathrm{T} 2$ 強調画像撮像法（ 以下高速SE法）を使用する機会を得たので，頭部における通常の T2強調画像撮像法（以下SE法）と画質・撮像時間等を比較し，有 用性を検討した。

[刘象] 健常人10名（男珄 9名，女性 1名，年龄25～36才）

[使用機器] 東芝MRT-200/FX III Super Version (1.5T)

$$
\text { （シールド型傾斜敗場コイル付き） }
$$

[万法］我々は，通常の頭部T2強調画像の撮像をSE法ではTR3000 msec, TE100msec, 加算回数 1 回で行っている。今回我々は高速SE 法の画質を評価する為，同一の対象にSE法と高速SE法の両者を施 行した。この際高速SE法では, SE法のTEの異なった画像の得られ ることが考えられたのでSE法のTEを $60,80,100 \mathrm{msec}$ と変化させ撮 像を行った。またSE法と同一の画筫を示す高速SE法のTRを探る為, 高速SE法のTRを1000〜 5000まで1000msecずっ変化させ撮像した。 加算回数は 1 回及び 2 回を用いた。

画質の評価については，おのおのの脳奉髄渡・白質・灰白質の信

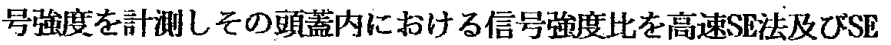
法で検討した。あわせて撮像時間の此较も行った。

[結果］1, 高速SE法とSE法の白質と灰白質の信号強度比を比較し た結果，高速SE法はTRが同じ場合，SE法のTEが 5 10msec短樎さ れたときの画像に近く（図.1), 高速SE法のTRを変化させた場合は, 高速SE法のTRが 300 500msec 延長されたときの画像に近かった

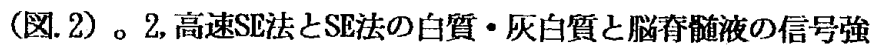
度比を比較した結果はほぼ同じであった（図.3）。3, 撮像時間は SE法が12分48秒かかるこころ高速SE法の1回加算ならば 2分33秒 で撮像することが出来た。4,加算回数は 1 回でも2回でも信号強 度比に有意な差はなかった。 [考察]マルチエコー法の原理より 当初我々が予想した結果が出た。脳脊能液に対する信号強度比に ついては予想と異なる結果が山たが，流れによる信号強度の変化 の為と思われる。
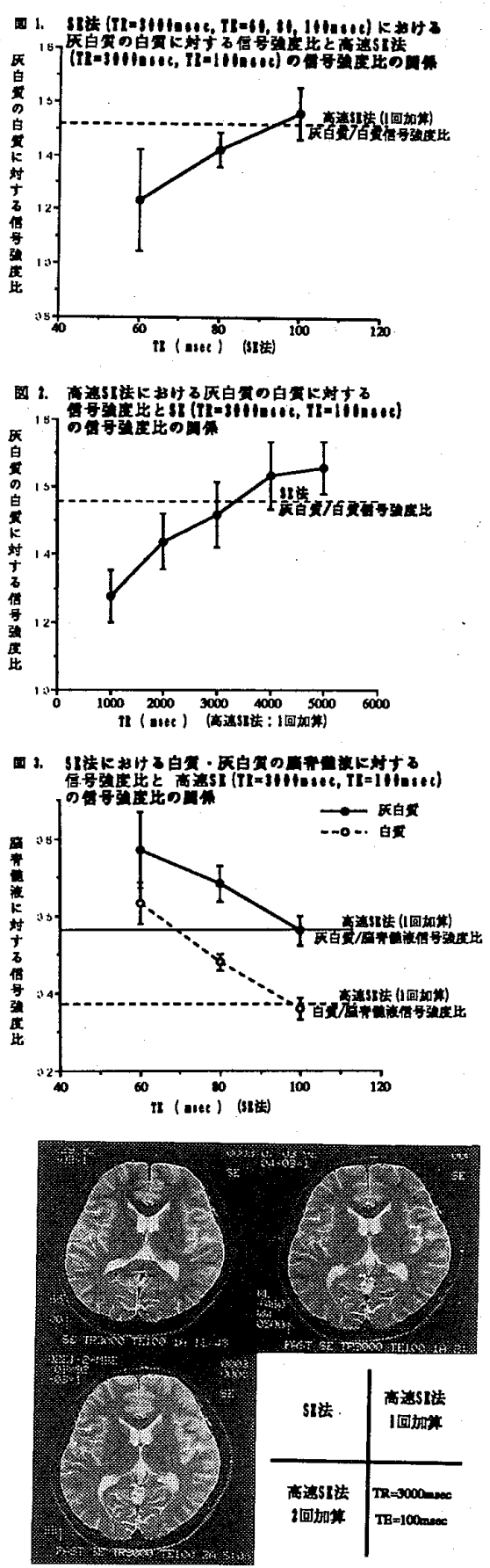